\title{
POTENSILATEN PREJUDICE DAL AM HUBUNGAN UMAT BERAGAMA
}

\author{
Oleh: Abd. Kadir Ahmad
}

\begin{abstract}
Abstrak
Bagaimana pun juga hubungan antar berbagai umat beragama akan terpola dalam bentuk harmonisasi dan konflik. Harmonis, jika para penganut agama mampu melokalisir energi keagamaan mereka dalam bentuk yang positif. Dan konflik, jika energi agama diarahkan kepada radikalisasi keyakinan.

Penelitian ini mengungkapkan kedua hal tersebut (harmonis dan konflik) dalam pandangan tokoh-tokoh agama dari dua agama besar yang memiliki tradisi yang panjang di Indonesia, yaitu Agama Islam dan Agama Kristen. Hasil penelitian menunjukkan bahwa potensi kerawanan sosial khusunya di kota Makassar sangat besar. Indikator utamanya adalah bahwa para tokoh agama mengungkapkan kekhawatiran akan posisi mereka dan kekhawatiran akan didominasi oleh kelompok lain.
\end{abstract}

\section{PENDAHULUAN}

\section{A. Latar Belakang Penelitian}

Dilihat dari kacamata Sosiologi, surabangan agama sangat penting demi kesinambungan masyarakat. Tetapi sebaliknya, agama pun sering mempunyai efek negatif terhadap masyarakat. Issu-issu keagamaan menjadi salah satu masalah penyebab konflik, keyakinan agama sering menimbulkan sikap tidak toleran; loyalitas agama hanya menyatukan beberapa orang tertentu dan memisahkan yang lainnya (Thomas F. O'dea, 1994:139). Artinya pengaruh agama memiliki dua sisi, yaitu pengaruh yang bersifat positif atau kohesif, tetapi di balik itu juga memiliki pengaruh yang membawa kepada disintegrasi atau bahkan destruktif (Joachim Wach, 1964 :35).

Sifat majemuk (pluralitas) dapat berupa keragaman bahasa, agama, lapisan sosial dan kasta, ras, dan kebudayaan suku bangsa. 
Keragaman dari segi agama lebih tinggi ketimbang dari segi etnis dan kebudayaan. Dalam satu etnis atau kebudayaan, tidak selalu menganut agama yang sama, sehingga agama dapat dikatakan merupakan variabel sosiologis yang paling beragam di dunia, disamping bahasa. Dalam sejarah, tidak ada sejarah yang bebas dari pemeluk agama lain kecuali Vatikan, Makkah dan Madinah. Bahkan negara-negara Islam di dunia Arab pun sampai sekarang masih mempunyai kelompok-kelompok minoritas Kristen dan Yahudi(NurcholisMadjid, 1992:178). Dalam kasus tertentu, perbedaan etnis sekaligus menjadi dasar bagi perbedaan agama. Ketenteraman dalam negara-negara dengan masyarakat-rriasyarakat multietnik tentu lebih sulit dijaga daripada dalam negara-negara dengan masyarakat yang seragam.

Bahwa Indonesia adalah bangsa majemuk didukung oleh kenyataan komposisi demografis (data kependudukan tahun 1990) dilihat dari pemeluk agama, yaitu Islam 87,21\%, Kristen Protestan 6,04\%, Katolik 3,58\%, Hindu $1,83 \%$, Budha $1,02 \%$ dan lain-lain (kepercayaan etnis lokal) $0,32 \%$ (Mustoha,MAdkk, 1997:9).

Pola pemukiman para pemeluk agama tersebut bervariasi menurut sejarah lokal dan perkembangan pemukiman. Meski Islam merupakan mayoritas secara nasional, akan tetapi secara lokal terdapat variasi dimana agama-agama lain yang menjadi mayoritas, seperti Bali mayoritas Hindu, Irian Jaya dan NTT mayoritas Kristen. Pola-variasi tersebut jugatampak sampai ke tingkat kabupaten, kecamatan, desa dan kampung-kampung. Polapola pemukiman pemeluk agama dengan demikian ada yang memperlihatkan pola konsentrasi pemeluk agama tertentu, dan ada juga pola menyebar dan segregasi.

Pada hakekatnya, baik secara sosiologis maupun doktrinal agamaagama di Indonesia telah membuktikan bahwa mereka itu agama yang toleran. Dalam perspektif agama-agama, dasar untuk hidup bersama dalam masyarakat pluralistik secara religius sejak semula telah dibangun di atas landasan normatif dan histroris sekaligus. Jika ada hambatan atau konflik disana sini penyebab utamanya bukan karena inti ajaran agama itu sendiri yang bersifat intoleran dan eksklusif, tetapi lebih banyak ditentukan dan dikondisikah oleh situasi historis-ekonomis-politis yang melingkari komunitas umat beragama. Kompetisi untuk menguasai sumber-sumber ekonomi, hegemoni politik dan kekuasaan jauh lebih mewarnai ketidakmesraan hubungan antar pemeluk agama dan bukannya kandungan ajaran agama itu sendiri (Abdullah, 1993). 
Itulah sebabnya maka faktor yang lebih potensial ke arah disintegrasi bangsa dalam kaitan hubungan umat beragama adalah bersumber dari masalah siapa yang mendapatkan apa dalam bidang politik, ekonomi, dan hegemoni kekuasaan. Masalah klassik ini, sesungguhnya tidak dapat lagi ditutup-tutupi untuk kepentingan sesaat, akan tetapi perlu secara terbuka diangkat dalam wacana perbincangan umum dan terbuka pada semua tingkatan dan lapisan masyarakat.

Pada tingkat grass root, kerukunan itu sesungguhnya sudah terbangun dengan sendirinya, dan ini real! Realitas sosial demikian sudah berjalan sepanjang sejarah kehadiran agama-agama dalam pola hidup koeksistensi dan kooperasi. Dan seperti disebutkan di atas, pengaruh siapa mendapatkan apa itulah yang sering menimbulkan masalah, dan ini terkait erat dengan peran para elit agama. Elit agamalah yang mampu mengartikulasikan faktor-faktor ekonomi, politik, dan kekuasaan di hadapan ummatnya. Oleh karena itu, dalam banyak hal eskalasi masalah yang timbul dalam hubungan antar umat beragama sangat ditentukan oleh elit agama di semua tingkatan. Peran tokoh agama di semua lini dengan demikian, amatlah menentukan masa depan kerukunan hidup beragama di Indonesia. Persamaan dan perbedaan pandangan para tokoh agama, dengan demikian, perlu ditangkap guna mendapatkan gambaran tentang posisi kerukunan hidup antar umat beragama. Hal itu terutama untuk mengaitkan persoalan yang terjadi antara idealisme semua agama untuk menegakkan kerukunan dan kenyataan di lapangan yang sering tidak konsisten dengan cita-cita ideal tersebut.

\section{B. Fokus Penelitian}

Yang menjadi fokus penelitian ini adalah berkisar pada pertanyaan: (1) Isu-isu apa yang dipandang penting oleh para tokoh agama berkaitan dengan kerukunan hidup beragama sekarang? (2) Bagaimana para tokoh agama tersebut menawarkan solusi?

\section{Tujuan Penelitian}

Penelitian ini bertujuan untuk mendapatkan gambaran mengenai persepsi tokoh agama berkaitan dinamika kerukunan hidup antar umat beragama, khususnya di Makassar. Dengan mengetahui gambaran tersebut akan lebih memudahkan terjalinnya berbagai dimensi hubungan antar umat beragama. Bagi Pemerintah, hasil penelitian akan sangat berguna sebagai salah satu bahan informasi (input) dalam mengambil langkah-langkah 
kebijakan guna mewujudkan peningkatan kualitas keberagamaan yang rukun, harmonis, dan lestari.

\section{Pengertian Konsep}

Yang dimaksud tokoh agama dalam penelitian ini adalah seseorang yang memiliki akses kepada umat beragama karena kedudukannya sebagai pemimpin organisasi keagamaan. Tokoh agama yang dimaksud adalah tokoh agama Kristen, khususnya Protestan dan Advent, dan tokoh Islam yang bersifat gerakah, seperti Dewan Dakwah Indonesia dan Komite Persiapan Penegakan Syariat Islam (KPPSI) Sulawesi Selatan.

Pada intinya kerukunan hidup beragama di Indonesia, adalah suatu kondisi yang menjamin terwujudnya secara langgeng dan elegan koeksistensi dan ko-operasi antar berbagai pemeluk agama yang ada. Secara teknis kerukunan itu mencakup tiga dimensi, yaitu kerukunan intern umat dalam satu agama, kerukunan antar umat yang berbeda agama, dan kerukunan antara umat beragama dengan pemerintah.

\section{E. Metode Penelitian}

Penelitian ini dilaksanakan di Kota Makassar dengan mengambil' kasus di Kelurahan Karampuang Kecamatan Panakukang. Kelurahan ini terletak di pusat kota Pengembangan Makassar dimana organisasiorganisasi keagamaan Islam dan Kristen berkantor. Di sini terdapat Kantor Advent Hari Ketujuh Masehi Sulawesi Selatan dan Tenggara yang terletak di Jalan Racing Centre. Juga terdapat kantor Persatuaji Gereja-gereja Indonesia Sulawesi Selatan dan Tenggara di jalan yang sama, menambah sisi dinamis pada kelurahan ini. Dewan Dakwah Islamiah Indonesia (DDII) Sulawesi Selatan juga berpusat disini dengan sebuah masjid (Masjid Alauddin) sebagai pusat kegiatan dan kantor. Masjid yang sama juga sering menjadi lokasi kegiatan organisasi gerakan penegakan syariat Islam, yaitu Komite Persiapan Penegakan Syariat Islam (KPPSI) Sulawesi Selatan. Keduanya getol memperjuangkan penegakan syariat Islam di Sulawesi Selatan. Di lokasi ini juga terletak perumahan dosen Universitas Muslim Indonesia (UMI) Makassar, termasuk di dalamnya rumah Ketua Yayasan, Rektor dan pejabat universitas kenamaan di Indonesia bagian timur tersebut. UMI banyak memfasilitasi pertemuan gagasan-gagasan kritis tentang penegakan syariat Islam. UMI sendiri membina civitas akademikanya melalui program kampus Island. 
Pengumpulan data dilakukan dengan menggunakan teknik wawancara mendalam. Teknik ini dipandang sesuai untuk mendalami pandangan tokoh-tokoh agama tersebut secara emik. Dalam hal tertentu dilakukan pengamatan terlibat, terutama untuk menangkap perspektif tokoh, misalnya, ketika menyampaikan khutbah atau ceramah.

Analisis data dilakukan secara berkesinambungan mulai dari kegiatan pengumpulan data sampai penarikan kesimpulan akhir. Dalam setiap tahapan wawancara ditarik kesimpulan sementara (hipotesis) yang selanjutnya kembali diverifikasi sesuai dengan kebutuhan. Karena itu proses analisis data berlangsung secara runtut mulai dari reduksi data, penyajian data, dan verifikasi data.

\section{PERSPEKTIF TEORITIS}

Bagi organisasi keagamaan, pemimpin organisasi adalah panutan bagi anggotanya. Seorang pemimpin pastilah memiliki sesuatu ajaran, ide, gagasan, dan prilaku yang patut menjadi pedoman bertindak atau dipanuti oleh anggotanya. Fungsi panutan ini dapat dijelaskan dengan menggunakan teori model for (model untuk) dan model o/(model dari) dari Clifford Geertz. Geertz mengatakan bahwa pola-pola kebudayaan merupakan model, sedangkan model itu sendiri memiliki dua arti yaitu "model dari" dan "model untuk". Pertama, apa yang ditekankan adalah manipulasi struktur-struktur simbol sehingga membawa struktur-struktur itu ke dalam kesejajaran dengan sistem nonsimbolis. Yang kedua, manipulasi sistem-sistem non simbolis menurut hubungan-hubungan yang terungkap dalam sistem-sistem simbolis (Geertz, 1973:93)

"Model untuk" yang berupapoladari sistem pengetahuan, gagasan, dan cita-cita suatu masyarakat tentang bagaimana seharusnya atau sebaiknya. "Model dari" adalah pola kehidupan yang hidup dalam realitas sosial, yang terkadang tidak jelas kaitannya dengan "model untuk" (Sairin, 2002:36). Jika Geertz melihat agama sebagai sistem simbol yang merupakan acuan untuk berperilaku, maka agama dalam hal ini berfungsi sebagai "model untuk", sedangkan realitas keberagamaan masyarakat merupakan "model dari", maka tokoh agama bagi komunitas agama adalah model yang mengandung kedua sisi tersebut. Tokoh agama sebagai model atau panutan merupakan perpaduan antara apa yang seharusnya dilakukan berdasarkan skema agama yang ada dan apa terjadi sebagai tuntutan realitas. Agama yang dihayati oleh orang-orang beragama pada suatu komunitas membentuk apa yang disebut komunitas orang-orang percaya atau komunitas spritual 
(spritual community) (TauFik Abdullah, 1987:62). Suatu komunitas, dengan demikian, akan memiliki kekhasan tersendiri di dalam mengkontruksi tokohnya. Tokoh agama sebagai panutan, membawa pengertian bahwa ia menjadi subyek atau nara sumber yang didatangi oleh masyarakat, dalam hal ini pengikutnya. Masyarakat datang untuk bertanya mengenai sesuatu hal yang pantas dan tidak pantas dilakukan.

Gambaran tentang "model" ini dipertajam oleh Michel Foucault melalui teorinya tentang parrhesiast (pewarta kebenaran). Menurutnya, kebenaran tidak akan muncul dengan sendirinya dalam sistem sosial dan kultural. Kebenaran terwujud melalui peran-peran sosial. Berkaitan dengan hal ini, ia memandang bahwa kebenaran harus dipahami sebagai praktek kuasa. Ia mengklaim bahwa sebagaimana kuasa selalu berubah dan terus menerus mentransformasikan dirinya sesuai dengan sejarah dan situasi manusia \{discourse), demikian pula kebenaran. Selanjutnya ia mengatakan bahwa kebenaran dibentuk oleh jaringan-jaringan praktek, prosedur, institusi, disiplin, dan pengetahuan yang saling bertaut dan perpadu. Ia menyebut jaringan-jaringan ini sebagai 'anatomi mikrofisik' atau 'anatomi politik', lewatnya kebenaran dijabarkan ke dalam hidup sehari-hari (Beoang, 1997:83).

Foucault mengatakan, kalau kebenaran harus dibawa ke dalam praktek hidup, atau kalau kebenaran harus dilihat sebagai suatu nilai dan praktek kuasa, maka siapakah yang dapat mengaturnya ? Siapakah pemegang nilai ? Dan siapakah yang mau mempraktekkannya ? Orang itu -menurut Foucault-adalah parrhaesiast atau pewarta kebenaran, subyek manusiawi yang dapat menerima dirinya dan orang lain, dan yang membutuhkan orang lain yang bisa membuat dirinya berarti. Beberapa aspek penting dalam aktivitas truth telling dikemukakan oleh Foucault. Pertama, dalam relasi parrhesiastik harus ada suatu obyek tertentu yang mau disampaikart atau diungkapkan Ini berhubungan dengan macam kebenaran tertentu yang harus dipandang dalam hubungan dengan praktek, hidup dan pengalaman. Kedua, harus ada seseorang yang dapat meneruskan kebenaran ini kepda orang lain, yaitu orang yang memiliki kebenaran itu dalam dirinya. Ketiga, cara orang menyampaikan kebenaran kepada orang lain. Disini yang paling penting adalah kepribadian atau persoalan moral dan etis seorang parrhesiast (Beoang, 1997:87). Dalam konteks hubungan antara seorang pemimpin agama dengan yang dipimpinnya, maka sosok truth telling atau parrhesiast bagi tokoh agama tersebut sangat relevan. 


\section{TEMUAN PENELITIAN}

\section{A. Dinamika Penduduk dan Pembangunan}

Sebelum tahun 1970-an daerah Panakkukang merupakan wilayah pinggiran dan masih merupakan bagian dari Kabupaten Gowa. Lahan yang masih kosong dimanfaatkan sebagai area persawahan. Selebihnya masih merupakan rawa-rawa. Penduduk Makassar memanfaatkan Panakkuang sebagai tempat untuk menikmati kehidupan yang masih alami dengan rumah-rumah panggung orang Makassar yang kelihatan tersebar dalam komunitas kampung per kampung. Ada kampung Masale, Kampung Tamamaung, Kampung Paropo, Kampung Karampuang, Pampang, Panaikang, dan sebagainya.

Kesan sebagai daerah pinggiran segera berubah setelah peta pengembangan kota merambah ke wilayah baru tersebut. Lahan yang terdiri dari daerah persawahan dan rawa-rawa tiba-tiba berubah menjadi kawasan kompleks perumahan dan pusat-pusat perbelanjaan dalam hitungan waktu yang singkat.

Panakkukang tidak lagi mencitrakan sejarah masa lampaunya. Tidak ada sesuatu pun yang tinggal kecuali kelompok-kelompok penduduk asli yang masih bertahan bersama dengan nama-nama kampung mereka yang tetap dilestarikan. Penduduk asli orang Makassar yang masih bertahan tinggal bagian kecil dari penduduk. Gelombang pembangunan kawasan baru menerpa mereka dengan tarikan material yang menggiurkan. Tanah-tanah mereka dijual kepada para pendatang dan pengembang, mereka kemudian menyingkir ke bagian kota lain.

Kantor Gubernur Sulawesi Selatan yang terletak di jalan poros ke keluar kota bagian utara adalah merupakan bagian dari wilayah baru ini. Begitu juga kehadiran Universitas Muslim Indonesia (UMI) Makassar, sebuah perguruan tinggi swasta paling bergengsi di kawasan Timur Indonesia, sebagai pengembangan dari Kampus I di pusat kota lama, juga menandai salah satu dinamika kecamatan Panakkukang. Landmark yang mencolok adalah pembangunan pusat-pusat perbelanjaan bergengsi di Makassar yang menyatu dengan kompleks perumahan elit dengan trade mark Panakkukang Mas, di bawah pengembang terkenal PT Asindo. Di sana ada Mai Panakkukang, Diamond, Pusat Grosir Mangga Dua Panakkukang Trade Centre, Matahari, dan paling terakhir Hipermart dan Carrefour. Kehadiran pusat-pusat perbelanjaan tersebut merupakan pusat penyesuaian gaya hidup cosmopolitan. Di dalamnya dapat dibeli apa saja mulai dari sayur mayur, makanan tradisional dan fast food, sampai mobil mewah, bahkan sampai 
kepada penjualan pelbagai jenis barang dengan harga serba Rp.5000 atau Rp. 15.000 sesuatu yang hanya kita pemah lihatdinegaraBarat. Setidaknya dua hari dalam seminggu Hipermart bahkan membuka kesempatan berbelanja selama $24 \mathrm{jam}$. Dunia -dengan demikian-seakan dilipat bukan saja dalam dimensi ruang tetapi juga dimensi waktu.

Di samping itu terdapatjuga simbol-simbol kapitalisme lainnya seperti Panakkukang Mas Country Club (PMCC), Fashion Park, dan fasilitas rekreasi serta perbelanjaan lainnya. Di luar itu ada pusat grosir Alfa yang hanya berjarak beberapa ratus meter dari Panakkuang Mas. Menjadilah "Panakkukang" bukan semata sebagai simbol administrasi pemerintahan, akan tetapi sebuah lambang dan merek dagang yang amat bergengsi.

Pemandangan kontras kemudian terlihat ketika kenyataan menunjukkan bahwa di samping pusat perdagangan serba ada tersebut, pedagang tradisional juga tetap berjuang untuk mempertahankan diri di pasar-pasar tradisional yang sumpek, jorok, dan becek.

Memang, masyarakat kelihatan tidak peduli sisi negatif dari perkembangan itu, bahkan mereka menikmatinya dan menjadikannya "kebanggaan." Perumahan yang ada di sekitar pusat perbelanjaan dan fasilitas lainnya mendapat nilai lebih. Bukan hanya anak-anak yang tergiur pada tarikan gaya hidup kapitalistik tersebut, tetapi juga orang dewasa.

Akan tetapi kalangan tertentu ada yang melihat perkembangan itu sebagai simbol-simbol kepentingan asing yang merambah masuk ke dalam wilayah domestik. Tahun 2001, peledakan terhadap KFC yang ada di Panakukang terjadi, hampir bersamaan dengan bom yang meledak di MacDonald dan Show Room Toyota.

Memang sebagai wilayah pengembangan kota Makassar, Panakkukang yang luas wilayahnya $13,03 \mathrm{~km}^{2}$ ini cukup dinamis dan plural baik dilihat dari segi penduduk dan agama maupun afiliasi kepentingan. Kecamatan Panakkukang yang diapit oleh Kecamatan Biringkanaya di sebelah Utara, Kecamatan Manggala di sebelah Timur, Kecamatan Tamalate di sebelah Selatan, dan Kecamatan Makassar di sebelah Barat, berpenduduk 127.238 jiwa (63.172 jiwa laki-laki dan 64.066 perempuan) (BPS Makassar, 2001). Kecamatan ini terdiri dari 11 (sebelas) kelurahan, salah satu di antaranya Kelurahan Karampuang yang menjadi tempat tinggal tokoh-tokoh agama.

- Dilihat dari aspek kelompok etnis penduduk Kecamatan Panakkukang meliputi etnis Makassar 38,050 \%, Bugis 35,314\%, Toraja $10.300 \%$, Mandar 1,328\%, Luwu 0,543, Jawa 4,137 \%,Duri 0,73\%, Selayar 0,693\%, dan lain-lain 4,433\% (Sensus Penduduk 2000). 
Kelompok-kelompok etnis tersebut mengalami pembauran sedemikian rupa dilihat dari tempat tinggal mereka khususnya pada kompleks perumahan. Namun demikian terdapat agregat-agregat, terutama bagi kelompokkelompok etnis yang tidak termasuk kewasan kompleks perumahan. Agregat-agregat kecil tersebut terbentuk secara alami dalam proses masa yang panjang. Penduduk asli Makassar sebagai penduduk asli wilayah ini masih dapat diidentifikasi dalam bentuk komunitas-komunitas kecil yang terpisah.

Salah satu kampiing yang menarik dari agregat tersebut dikenal dengan Kampung Rama, singkatan dari Rantepao - Makale. Penduduknya adalah kelompok etnis Toraja yang beragama Kristen, dari dua daerah di Kabupaten Tana Toraja, Rantepao dan Makale. Meski terjadi agregasi antara etnis Toraja yang beragama Kristen dan etnis-etnis lain yang beragama Islam, hubungan mereka tergolong harmonis.

Jumlah penduduk menurut agama meliputi : Islam 173.471 orang (86\%), Katolik 6.966 orang (3,5\%), Protestan 19.359 orang $(9,6 \%)$, Hindu 368 orang $(0,18 \%)$, Budha 573 orang $(0,28 \%)$, dan lainnya 205 orang $(0,10 \%)$. Sedangkan tempat ibadah terdiri dari 74 mesjid dan 19 gereja.

\section{B. Bahaya Laten dalam Pandangan Tokoh Agama}

Meski tidak terjadi konflik an tar warga sebagai akibat dari pluralitas agama dan etnik namun kerawanan sosial atau potensi konflik tetap ada. Potensi itu apabila tidak dikelola dengan baik bisa berkembang menjadi aktual. H.Aswar Hasan, Pengurus Dewan Dakwah Islamiyah (DDII) Sulawesi Selatan, mengatakan di antara faktor kerawanan antara lain adalah prasangka atau prejudice. Ia menjelaskan :

Kerawananan sekarang ini adalah sikap kaum muslimin yang hanya memandang kepada kaum non-muslim, sebagai yang menunjukkan sifat-sifat dan tingkah laku dan cara-cara yang dianggap melakukan intervensi internal sikap keagamaan dengan adanya isu misionaris dakwah keagamaan sampai kepada misionaris bangunan-bangunan, seperti bangunan rumah ibadah.

Prasangka semacam itu dapat menjadi pemicu konflik. Istilah misionaris dakwah keagamaan dimaksudkan sebagai cara yang dilakukan penganut agama tertentu untuk mempengaruhi penganut agama lain. Sementara misionaris bangunan rumah ibadah dimaksudkan sebagai membangun rumah ibadah pada komunitas bukan penganut agama yang 
membangun, atau setidak-tidaknya di tempat itu belum layak dibangun sebuah rumah ibadah.

Sering terjadi protes dari kelompok umat Islam mengenai pembangunan rumah ibadah oleh umat Kristiani. Hal itu terjadi manakala di suatu tempat terjadi hal seperti dimaksudkan di atas. Tahun 2001 komunitas Islam di Jalan Racing Centre yang terletak di Kelurahan Karampuang, melakukan aksi protes berupa pengumpulan tanda tangan warga untuk menolak pembangunan sebuah gedung yang ada di jalan tersebut. Gedung itu tepat berada di sudut jalan berbatasan dengan kompleks perumahan UMI, tidak jauh dari mesjid Alauddin. Gedung itu kemudian diketahui sebagai kantor Persatuan Gereja-gereja Indonesia Sulselra. Bangunan ini didesain berlantai tiga. Rencana pembangunannya sudah berlangsung lama dan izinnya diperoleh dari Gubernur H.Z.B.Palaguna. Menurut keterangan pihak PGI, bahwa yang menunjukkan lokasi bangunan itu adalah Gubernur sendiri. "Saya masih ingat dulu, beliau datang ke lokasi ini meninjau dengan pakai celana pendek", katanya. Bangunan tersebut dibangun atas swadaya umat Protestan.

Mengenai protes yang dilakukan oleh warga muslim tersebut diakui oleh pihak PGI. Pendeta Yakob Kila Rumbi dari Persatuan GerejaGereja Indonesia Sulselra menjelaskan:

Memang dulu sejak awal dibangunnya kantor ini ada surat protes masuk dari keluarga besar UMI, tapi itu karena tidak jelasnya informasi pada mereka, yang disangkannya ini adalah gereja, padahal tidak, ini bukan sarana ibadah, tapi kantor PGI yang menghimpun semua gereja-gereja, untuk berbicara tentang pelayanan umat di bidang kesehatan, ekonomi, dan masalah-masalah sosial lainnya.Tapi setelah mereka tahu tujuan pendirian gedung ini sebenarnya, sampai sekarang sudah tidak ada protes dari masyarakat.

Kantor Advent yang tidak jauh dari Kantor PGI juga pernah mengalami ancaman berupa teror dari orang tidak dikenal. Pendeta Hepi Sibilang (Pendeta Advent Hari Ketujuh Masehi) menceriterakan :

Tiga tahun lalu, pernah mendapat serangan, lemparan, kalau tidak salah, lemparan bom rakitan. Saya kebetulan ada di tempat itu, dan merasa ketakutan, bahkan trauma itu masih ada sampai sekarang, itulah yang terbentur di dalam otak saya. Tetapi saya sendiri tidak memahami sumber lemparan tersebut dan siapa pelakunya. 
Pendeta sendiri merasa trauma dengan peristiwa itu. Salah satu cara untuk mengatasi rasa takut atau trauma itu, ia mengaku kembali kepada prinsip keimanan yang dianutnya. "Dari segi umat yang percaya kepada Tuhan", katanya, "walaupun saya mengalami trauma, tetapi saya berasumsi bahwa kalau ditampar pipi kiri dikasih pipi kanan, kami percaya adanya perlindungan Tuhan. Demikian juga dengan peristiwa itu, kami tetap was was, tetapi kami tetap bekerja seperti biasa, yakin ada perlindungan Tuhan. Diawali dengan doa, diakhiri dengan doa. Itulah kuncinya.

Kantor Gereja Advent Masehi Hari Ketujuh Sulselra ini bertempat di jalan Racing Centre, jalan menuju tempat perumahan UMI dari arah Kantor Gubernur di Utara. Fungsi kantor sifatnya umum, ada pelayanan kesehatan, dan kegiatan pertemuan Konferensi Tahunan Wilayah Sulawesi Selatan Tenggara. Sebelum dibangun panitia sudah mengantongi izin dari Pemerintah.

Drs.H.Paita Halim, pengurus Komite Persiapan Penegakan Syariat Islam Sulawesi Selatan (KPPSI) dan Dewan Dakwah Islam Indonesia (DDII) menjelaskan mengapa timbul reaksi dari warga mengenai pembangunan kedua gedung tersebut. Alasan yang paling penting adalah untuk menghindari fitnah. Menurut Paita, keberadaan bangunan milik orang Kristen itu sama sekali tidak merupakan ancaman bagi warga yang beragama Islam. Masalah yang dianggap penting adalah agar persatuan dan kesatuan tidak tercemar akibat adanya fitnah. Paita menegaskan :

Kita khawatir (sarana itu) dimanfaatkan oleh pihak ketiga. Sebagai contoh, dibom saja gereja ini, siapa lagi yang dituduh kalau bukan keluarga besar UMI, berarti umat Islam, padahal bisa saja ini berasal dari pihak lain. Dan ini sebenarnya dipicu oleh orang-orang yang menghendaki kerusuhan.

Suasana tidak saling percaya di masyarakat menimbulkan kecurigaan antar warga apalagi yang berbeda agama dan atau suku. Berita yang dilangsir oleh media massa di sekitar peristiwa-peristiwa konflik dengan segala bentuknya yang tidak selalu mudah diungkap ujung pangkalnya membuat warga bersikap hati-hati. Salah persepsi mengenai kelompok penganut agama oleh kelompok yang lain sering menjadi sumber terjadinya kerawanan dalam hubungan antar dan intern umat beragama. Hal itu antaa lain disebabkan karena adanya apa yang diistilahkan oleh mereka sebagai prejudice atau prasangka mengenai penganut agama. Pembangunan rumah 
ibadah oleh umat Kristen tidak jarang menjadi sasaran kecurigaan atau prasangka tersebut. Dianggapnya pembangunan rumah ibadah tersebut sebagai salah satu bentuk missi untuk menarik penganut agama ke dalam agama Kristen.

Kedua peristiwa tersebut dapat dianggap sebagai kerawanan laten yang sewaktu-waktu dapat menjadi ancaman terhadap keharmonisan hubungan antara kelompok agama di dalam masyarakat Karampuang. Meskipun pada akhirnya ternyata bahaya itu tidak terjadi karena cenderung tidak ditanggapi secara emosional, namun eskalasi persoalan laten tersebut jangan sampai terjadi.

Bahaya laten itu sendiri bukan hanya terjadi antara kelompok Muslim dan non Muslim, akan tetapi juga antara mereka yang termasuk dalam agama yang sama tetapi dengan orientasi pemikiran dan tata cara ibadah yang berbeda. Dalam masyarakat Islam kelompok yang berbeda aliran dapat terefleksikan dalam bentuk mesjid yang diberikan label sesuai dengan organisasi yang mendirikannya, tetapi tidak seekstrim dalam agama Kristen. Orang-orang Islam yang berlatar belakang tradisi keagamaan, pemikiran keagamaan dan cita-cita politik yang berbeda kelihatan dapat bersatu dalam sebuah mesjid. Kalau ada hal-hal yang sulit dikompromikan dalam praktek paling ekstrim kelompok yang tidak terakomodasi akan mengambil sikap menarik diri karena mereka tahu bahwa mesjid itu memang dikendalikan oleh sebuah organisasi yang bukan "milik" mereka. Bentuk menarik diri tersebut akan terlihat pada berkurangnya intensitas kunjungan jamaah dari mereka yang tidak sealiran dan tidak terakomodasi detail ritual yang dimilikinya. Cara lain yang dilakukan adalah dengan mencari mesjid yang sealiran meskipun berada di luar komunitasnya.

Di dalam Kristen perbedaan itu lebih jelas lagi ditandai dengan perbedaan gereja. Hal ini terkait dengan aliran yang mereka anut. Pendeta Yakob Kila Rumbi dari Persatuan Gereja-Gereja Indonesia Sulselra mengatakan, perlu dibedakan antara aliran dan sekte. Aliran itu seperti Protestan, Katolik, dan Advent, sedangkan sekte itu sempalan-sempalan yang sesat dalam pelaksanaannya, artinya keluar dari ajaran Kitab. Yang termasuk sekte misalnya kasus Pondok Nabi, yang mengatakan Kiamat terjadi pada tanggal 10-11-2003. "Siapa yang bisa menentukan Kiamat, tidak ada umat manusia yang bisa menentukan ini, makanya aliran ini dianggap sesat", kata pendeta Yakob. Yakob menjelaskan : 
Sebenarnya, tidak ada perbedaan antara aliran di dalam Kristen; hanya liturgi-nya (cara peribadatannya) yang berbeda. Ada yang beribadah dengan menyanyi memuji Allah, ada yang loncat-loncat. Protestan, berarti protes. Waktu itu Marthin Luther (1517) memprotes ajaran gereja, makanya berdiri sendirilah Martin Luther ini dengan pengikutnya. Tapi kemudian ada yang tidak sependapat dengan interpretasi Kitab, kemudian mereka membentuk kelompok tersendiri, dan medirikan gereja baru lagi. Di Kristen itu kan istilahnya pengikut atau umat. Jadi hanya menjalankan ibadah di gerejanya masingmasing yang merupakan alirannya. Di Kristen itu ada kurang lebih 300 aliran untuk sekarang ini. Istilahnya satu akar akan memunculkan sepuluh akar. Dengan perbedaan ini kami disatukan oleh ajaran Universal yaitu ajaran Kasih, yaitu mengasihi sesama manusia.

Apabila ratusan aliran itu dengan sikap ajaran eksklusifnya masingmasing berada dalam satu daerah, dapat diperkirakan betapa umat Kristiani memerlukan banyak sekali jenis gereja. Dan karena itu dapat dipahami kalau gereja akan banyak bertebaran dimana-mana sesuai dengan persebaran kelompok aliran di bawah agama Kristen.

Pendeta Advent Had Ketujuh juga mengakui hal yang sama. Menurut Pendeta Hepi Sibilang, banyak sekte dan mazhab di dalam Kristen lahir sebagai akibat dari perbedaan interpretasi dalam pengertian ada tulisantulisan yang masing-masing penganut sebelumnya dijadikan pegangan. Tetapi sebenarnya Al-Kitab sendiri itu sama, interpretasi yang berbeda. Tetapi ada ajaran yang sifatnya sama diadopsi oleh semua agama Kristiani, yang dikenal dengan Golden True, yang ada hubungannya dengan masyarakat, yaitu "kasihilah sesama manusia seperti dirimu sendiri".

Gereja Advent menerima Al-Kitab secara keseluruhan bersama ajaran-ajarannya, salah satu doktrinnya adalah Kebaktian Hari Sabtu, ini berbeda dengan yang lainnya yang melakukan kebaktian Hari Minggu. Yang mencolok dari yang lainnya, adalah dari segi makanan dan minuman. Mereka masih tetap percaya pada Al-Kitab bahwa ada kategori halal - haram. Minuman anggur dan yang mengandung alkohol sifatnya larangan. "Termasuk merokok, masuk dalam kategori doktrinasi. ladi prinsipnya yang merusak kesehatan itu bagi kami adalah larangan. Masuk doktrin, bukan sekedar larangan biasa, kata Pendeta Hepi.

Keadaan seperti itu bisa saja merupakan faktor rawan dalam hubungan intern umat dan antar umat beragama. Pendeta mengakui bahwa konflik dalam artian perusakan kemungkinannya kecil, hanya saja yang 
berpeluang terjadi adalah kecemburuan dan adanyatarik menarik jamaah. Misalnya, seorang yang mulanya melakukan ibadah di gereja ini, tetapi kemudian hari tertarik untuk melakukan ibadah di gereja lain karena tertarik dengan liturgi-nya, kemudian pindah. Di sini biasa timbul masalah. Mereka biasa pindah karena menganggap. tidak berkesan dengan melakukan ibadah hanya dengan melakukan puji-pujian, tapi lebih tertarik jika ibadah itu dilakukan dengan tari-tarian.

Poin pentingnya adalah bahwa di kalangan Kristen setiap aliran dan sub-aliran memiliki gerejanya sendiri-sendiri. Mereka tidak saling melintasi gereja untuk beribadah. Itulah sebabnya setiap komunitas Kristen selalu berusaha untuk mendirikan gereja sendiri, atau mereka akan mencari gereja sejenis meskipun di luar komunitas tempat tinggalnya. Hal inilah yang tidak jarang disalahpahami oleh orang-orang Islam bahwa pembangunan rumah ibadah semacam itu merupakan suatu metode untuk mempengaruhi umat di luar Kristen. Artinya pembangunan rumah ibadah bagi aliran atau sub-aliran tertentu merupakan konsekuensi dari ajaran Kristen. Berbeda dengan Islam, umatnya dapat melakukan shalat pada mesjid mana pun yang mereka suka.

Prasangka lain yang sering muncul dalam hubungan antar umat beragama adalah apa yang oleh pihak Kristen disebutkan sebagai aktualisasi dari ajaran kasih. Menurut Yakob, ajaran kasih artinya berbagi kasih kepada sesama manusia, terutamajika di antara kita ada yang kesulitan, kekurangan atau ditimpa musibah maka ditumbuhkan rasa empati untuk menolong umat tersebut, walaupun di luar jamaah kita. Ajaran kasih dalam Kristen tidak mengenal batas agama dan keyakinan. Cinta kasih tanpa sekat agama atau keyakinan inilah yang dipraktekkan oleh orang Kristen untuk menyantuni orang-orang yang ditimpa kesulitan hidup. Yakob mengakui bahwa ajaran kasih itu tidak selamanya diterima baik oleh sebagian orang. Bahkan sebaliknya sering dianggap sebagai salah satu bentuk missi agama. Yakob mengatakan:

Maaf, ajaran kasih seperti ini, sering disalahartikan orang-orang di luar agama kami yang menganggap kami mau menolong karena kepentingan misi penyebaran agama. Padahal tidak. Contoh musibah banjir yang pernah terjadi di Kabupaten Wajo, kami datang dan kami memberikan bantuan kepada saudara-saudara kami di sana. Ajaran kasih itu terdapat dalam kitab Matius. 
Bukan rahasia lagi bahwa rasa empati se mengundang kecurigaan dari kalangan orang-orang Isla prasangka terhadap tindakan kemanusiaan seperti itu. Te yang sering diangkat adalah jangan menjual iman dengan se Tidak jelas seberapa banyakkah orang yang ditolong itu ] agama. Kalau toh beralih agama boleh jadi mungkin kai bukan seorang beriman yang baik, sehingga mudah mel agama dengan imbalan sesuap nasi. Prasangka semacam i dihilangkan dengan membangun srkap keterbukaan dan sal: Hal-hal yang bersifat laten seperti dikemukakan di atas $m$ yang sewaktu-waktu dapat tersulut oleh faktor-faktor lain $\mathrm{c}$ dan aliran.

Drs.H.PaitaHalim, M.Ag menyatakan hal menari laten yang bisa menyulut keberingasan dan kles antar kelo kalau sebuah kezaliman dan kemaksiatan sudah dibiarkan rx dampaknya akan lebih berbahaya daripada isu yang lain, konflik tidak terjadi dengan sendirinya, melainkan terdapat $\mathrm{f}$ mendahului. Salah satu yang mendahului itu adalah apa sikap atau perilaku "keterlaluan". Paita menyatakan:

\begin{abstract}
Manakala pada satu tempat terjadi semacam "keterl larangan-larangan, tapijustru dibiarkan oleh masyara pergaulan bebas muda mudi, minum-minuman keras, adi yang tidak dapat melihat yang semacam itu, maka tida lain, mengamuk. Alasannya untuk menyelamatkan mas) kelompoknya, sampai menyelamatkan ajaran akidahnj keyakinan bahwa kalau kita biarkan berlarut-larut berart lambat pasti kita akan kena azab dari Allah.
\end{abstract}

Itulah yang melatari aksi peledakan bom yang dilak orang yang memilih jalan seperti itu sebagai salah satu bentu seperti Amrozi dan kawan-kawan. Mereka sangat se hukuman yang dijatuhkan oleh pengadilan. Bahkan dia men Akbar".

Paita Halim juga melihat ada kelompok lain menciptakan hal-hal semacam itu supaya mempunya melakukan kerusuhan. Yang membuat kerusuhan adalah masyarakat, utamanya musuh agama. Siapa yang melakukai boleh menuduh tetapi yang mengkoordinir adalah ore 
memusuhi Islam", katanya. Anehnya , Paita menamb Muslim yang belum tahu tentang syariatnya juga $1<$ memberi contoh konflik Poso dan Ambon, awalnyac misalnya minuman keras.

Aksi-aksi kekerasan seperti itu kelihatannya $r$ yang seide dan kemudian melakukan aksi bersama, $s$ disebutkan sebagai jihad. Akan tetapi tidak menutup ini akan menjadi satu kelompok, jika pemerintah tida akan muncul Amrozi dan Imam Samudra di mana-r Itu terjadi kalau keadaan berlarut-larut tanpa antisipasi < mengatasi kemaksiatan dan keonaran.

Bentuk kekerasan dan konflik yang terjadi $\mathrm{m}<$ Tuhan kepada manusia, utamanya ulama, cendekiawar dan kiai, agar mereka mau berbicara terus menerus terjadi hal yang demikian. Paita berpendapat bahv segala bentuknya adalah salah satu peringatan. Per langsung dari Allah, berupa banjir, longsor, api, dan se semua itu di samping sebagai ujian, juga karena tin sudah tidak bisa ditolerir lagi.

Dengan demikian, menurut Paita Halim, bahay bukan karena faktor perbedaan agama atau keyakin; keonaran yang bisa bersumber dari umat beragama saja. Keonaranlah yang menyebabkan timbulnya real akibat. Keonaran itulah yang diatasi oleh umat Islam ] revolusioner, yang tidak melihat lagi cara lain yang le! boleh buat hams radikal, sama dengan kasus bo Paita.

Dalam konteks inilah maka KPPSI berusah< kemaksiatan dan keonaran dapat diredam serendah $\mathrm{n}$ pemberian hukum secara lebih tegas dari hukum aga dianggap efektif untuk mengatasi masalah bangsa yanj jalan untuk sampai ke sana masih harus menui sebagaimana hasil temuan tim pengkajian pemberlakm Islam masih berbeda pandangan mengenai cara $\mathrm{p}<$ tersebut apakah secara formal atau substansial. 


\section{Pembahasan dan Solusi}

Indonesia adalah bangsa majemuk. Hal ini didukung oleh kenyataan komposisi demografis (data kependudukan tahun 1990) dilihat dari pemeluk agama, yaitu Islam 87,21\%, Kristen Protestan 6,04\%, Katolik 3,58\%, Hindu $1,83 \%$, Budha $1,02 \%$ dan lain-lain (kepercayaan etnis lokal) $0,32 \%$ (Mustoha dkk , 1997: .9). Komposisi itu tidak banyak bergeser sampai sekarang. Pola pemukiman para pemeluk agama tersebut bervariasi menurut sejarah lokal dan perkembangan pemukiman. Meski Islam merupakan mayoritas secara nasional, akan tetapi secara lokal terdapat variasi dimana agamaagama lain yang menjadi mayoritas, seperti Bali mayoritas Hindu, Irian Jaya dan NTT mayoritas Kristen. Pola variasi tersebut juga tampak sampai ke tingkat kabupaten, kecamatan, desa dan kampung-kampung. Pola-pola pemukiman pemeluk agama dengan demikian ada yang memperlihatkan pola konsentrasi pemeluk agama tertentu, dan adajuga pola menyebar dan segregasi.

Sifat majemuk (pluralitas) dapat berupa keragaman bahasa, agama, lapisan sosial dan kasta, ras, dan kebudayaan suku bangsa. Keanekawarnaan itu pada umumnya terdapat dalam negara-negara yang sedang berkembang, akan tetapi adakalanya juga terdapat pada negara-negara maju. Dari sejumlah anggota Persatuan Bangsa-Bangsa, hanya 17 negara yang mempunyai kebudayaan yang sama dengan suku bangsa yang dominan, yaitu Austria, Botsuana, Denmark, Jerman, Eslandia, Irlandia, Jepang, Korea Utara, Korea Selatan, Lesotho, Luxemburg, Negri Belanda, Norwegia, Portugal, Somalia, dan Negara Swazi (Koentjaraningrat, 1988: 356).

Keragaman dari segi agama lebih tinggi ketimbang dari segi etnis dan kebudayaan. Dalam satu etnis atau kebudayaan, tidak selalu menganut agama yang sama, sehingga agama dapat dikatakan merupakan variabel sosiologis yang paling beragam di dunia di samping bahasa. Dalam sejarah tidak ada sejarah yang bebas dari pemeluk agama lain kecuali Vatikan, Makkah dan Madinah. Bahkan negara-negara Islam di dunia Arab pun sampai sekarang masih mempunyai kelompok-kelompok minoritas Kristen dan Yahudi (Madjid, 1992:178). Dalam kasus tertentu, perbedaan etnis sekaligus menjadi dasar bagi perbedaan agama.

Ketenteraman dalam negara-negara dengan masyarakatmasyarakat multietnik tentu lebih sulit dijaga daripada dalam negara-negara denga masyarakat yang seragam. Variabel ekonomi tidak selalu merupakan faktor determinan bagi kerawanan hubungan antar etnik dan kebudayaan. 
Pendirian bahwa di dalam negara yang telah maju ekonominya kaanekaragaman kebudayaan suku bangsa tidak akan mengganggu ketenteraman negara karena penduduknya sudah merasa puas dengan kemakmuran yang tercapai dan dapat berfikir dengan rasional dan praktis, tak dibenarkan oleh peristiwa-peristiwa konflik antar suku.

Pada intinya kerukunan hidup beragama di Indonesia, adalah suatu kondisi yang menjamin terwujudnya secara langgeng dan elegan koeksistensi dan ko-operasi antar berbagai pemeluk agama yang ada. Secara teknis kerukunan itu mencakup tiga dimensi, yaitu kerukunan intern umat dalam satu agama, kerukunan antar umat yang berbeda agama, dan kerukunan antara umat beragama dengan pemerintah.

Platform kerukunan hidup beragama mengandung substansi bahwa di dalam negara Republik Indonesia terdapat bermacam-macam agama Islam, Kristen Katolik, Kristen Protestan, Hindu, Budha, kita bergaul dengan saudara-saudara tersebut sebagai satu bangsa, satu tanah air. Dalam platform itu juga diharapkan setiap umat beragama dapat saling bertemu, menyebabkan terbentuknya berbagai forum konsultasi, forum dialog, musyawarah, sekretariat bersama dan sebagainya. Setiap umat beragama mempunyai tekad untuk menciptakan kerukunan demi keutuhan dan stabilitas nasional guna tercapainya tujuan hidup bersama sebagai bangsa. Perlunya komitmen terhadap landasan yang sama, disetujui bersama, dan ditaati bersama: Pancasila, UUD 1945, dan ikatan-ikatan lainnya. Bahwa kerukunan tidak cukup sebatas tidak mengganggu dan merugikan pihak lain melainkan mewujudkannya dalam bentuk kerjasama yang kongkrit dalam berbagai bidang kehidupan.

Secara sosiologis agama memiliki potensi integrasi dan konflik. Hal itu disebabkan bahwa keHka wahyu memasuki sejarah, memasuki dimensi ruang dan waktu, memasuki komunitas manusia, maka pilihan dan perilaku komunitasnyalah yang memberi warna wahyu itu (Denni J.A. 1990:4)

Secara formal, infrastruktur untuk menjamin kondisi hidup rukun antar pelbagai interaksi sosial umat beragama kiranya sudah memadai. Berbagai perangkat perundang-undangan dan peraturan telah meng-cover kebutuhan akan kerukunan tersebut. Mulai dari Pancasila sendiri, sebagai dasar negara, Undang-Undang Dasar 1945 (pasal 29), dan Peraturan Pemerintah. Hampir semua aspek yang menyimpan titik-titik rawan, misalnya tata cara penyebaran agama, tata cara pendirian rumah ibadah, sudah ada aturannya. Makajika masih terjadi masalah di sekitar kerukunan hidup beragama, itu disebabkan karena pendekatan yang terlalu formalistik 
Maka dalam uraian ini penulis akan mengemukakan lembaga lokal sebagai alternatif bagi pemecahan krisis hubungan sosial umat beragama.

Krisis hubungan antar umat beragama sesungguhnya karena tidak diberdayakannya pranata dan institusi tingkat bawah di satu pihak dan terlalu kuatnya pendekatan top down di pihak lain. Selama ini, semuanya datang dari atas, sehingga apresiasi terhadap lembaga-lembaga tingkat bawah yang sudah berkembang melalui dialektika dan dinamika alami masyarakat bersangkutan lumpuh. Nilai-nilai yang selama ini menjadi bagian dari pangngaderreng seperti penghargaan terhadap ketentuan adat (ade'), sistem peradilan (bicara), hal-hal yang dianggap wajar (rapang), struktur sosial (wari), dan norma-norma agama (sara') seakan tidak menemukan lagi posisi yang layak dalam realitas kehidupan sosial masyarakat kita. Hal itu pada gilirannya menyentuh masalah yang paling rawan yaitu wilayah kehidupan keagamaan, yang karena menyangkut masalah yang amat esensial dan rawan harus menempati posisi yang stratregis dan mendapatkan platform yang jelas dalam sistem budaya dan sosial masyarakat. Pengembangan institusi sara' di samping ade' adalah sebuah antisipasi yang sangat substansial guna tidak saja agar pengembangun agama dapat berjalan dengan wajar, akan tetapi juga dalam rangka mempersempit kesenjangan hubungan antar agama. Pendekatan budaya dengan demikian tetap merupakan cara terbaik dalam rangka meredam hal-hal yang tidak diinginkan dalam hubungan antar umat beragama dan dengan pemerintah.

Setelah terbukti pendekatan yang terlalu berbau dipaksakan dari atas mengalami kegagalan, maka pilihan satu-satunya untuk kedepan adalah penguatan budaya lokal. Pertimbangan ke arah itu adalah bahwa pendekatan budaya lokal lebih bersifat alami daripada artifisial, lebih efisien dilihat dari berbagai sudut. Faktor faktor yang perlu diperhatikan adalah jaminan bahwa kelompok marginal dapat terlibat secara penuh. Kenyataan menunjukkan kelompok marginal dalam masyarakat baik karena kuantitasnya yang sedikit, kemampuannya di bidang ekonomi, pendidikan, maupun faktor lain yang di anggap lebih rendah, merupakan salah satu bentuk pelecehan terhadap orang lain. Dan pada gilirannya menjadi bibit munculnya kecemburuan sosial dan akhirnya konflik. Forum atau apapun bentuknya selalu harus melakukan pertemuan secara rutin dan intensif. Jaringan ganda dengan berbagai organisasi yang sama dan dengan pemerintah baik pada tingkat yang sama maupun pada tingkatan lebih tinggi senantiasa harus dikembangkan dan dibina. 
Untuk menjamin berperannya forum tersebut diperlukan berbagai input baik dalam bentuk training, insentif dana, dan pengetahuan tertentu. Dalam pada itu, mekanisme harus dikembangkan yang menjamin keterlibatan masyarakat secara penuh dalam forum, dan juga layanan kepada masyarakat akan berbagai masalah yang dihadapi.

Dalam kondisi seperti itu, masyarakat harus dikondisikan sedemikian rupa untuk memahami kerawanan (vulnerability) yang kadang-kadang tidak tampak tetapi potensial untuk timbulnya konflik, senantiasa didorong untuk melakukan pilihan-pilihan dalam menghadapi masalah berpartipasi secara penuh dengan menggunakan sumberdaya sendiri (tenaga, dana, dan pengetahuan), partisipasi dalam proses pengambilan keputusan; dan mencari bantuan dari luar sebatas keperluan.

Dalam forum itu, masyarakat dituntut kepekaan untuk menganalisis gejala-gejala timbulnya konflik guna meredam sedini mungkin dan mampu memproyeksikan jika gejala itu berlanjut. Biasanya bibit-bibit konflik berangkat dari hal-hal yang kecil dan sepele. Karena sifatnya sepele, akibat yang ditimbulkannya juga terkesan hanya berupa kecemasan kecil dan karena itu respon yang diberikan masyarakat terhadap gejala tersebut juga terkesan seadanya. Dalam menghadapi gejala seperti ini diperlukan proses penyadaran dini lewat pemberian pengetahuan akan bibit-bibit konflik tersebut dan bagaimana cara menyelesaikannya agar tidak menjadi besar. Tahap berikutnya ditandai dengan sudah munculnya korban-korban meski dalam skala kecil misalnya kekecewaan-kekecewaan, pengelompokanpengelompokan yang terkesan terpisah dari akses forum yang dibina bersama. Akibat psikologis dari gejala tersebut adalah semakin banyaknya warga yang merasakan kecemasan akan timbulnya masalah dalam kehidupan bersama. Sikap yang muncul biasanya dalam bentuk stigma kepada kelompok tertentu atau menarik diri dari hubungan sosial. Untuk menghadapi hal tersebut diperlukan proses pendekatan yang lebih intensif pula, penyadaran dan pemberian pengetahuan yang lebih luas akan bahaya konflik, dan terus menerus memulihkan sampai tuntas orang-orang yang mengalami masalah dan krisis hubungan antar warga.

Pada tingkat tertinggi adalah gejala-gejala tadi tidak dapat lagi dilokalisir, dan sudah merupakan issu umum dalam kelompok masyarakat dan siap untuk meledak. Akibat psikologis yang ditimbulkannya adalah berupa kecemasan umum, kemarahan, memuncaknya saling tuding (stigma) dan timbulnya perasaan frustrasi atau fatalistik pada kalangan tertentu. Jika ini 
terjadi, maka respon yang perlu dilakukan adalah juga bersifat massif (broad based responses) dan menyentuh akar masalah yang sebenarnya.

\section{KESIMPULAN}

Rekaman pandangan dari para tokoh agama Islam yang berlatarbelakang Islam formal dan Kristen ini memunculkan beberapa isu di sekitar hubungan antar umat beragama yang masih perlu mendapat perhatian serius dari semua kalangan yaitu :

1. Hubungan antar umat beragama masih menyimpan titik-titik rawan karena masih adanya kecurigaan atau prejudice (prasangka) yang memang merupakan masalah klasik dalam hubungan umat beragama. Prejudice yang dimaksud adalah isu di sekitar pendirian fasilitas organisasi keagamaan yang disalahgunakan menjadi rumah ibadah dan rumah ibadah yang dibangun tanpa melalui prosedur yang benar (setidaknya menurut penganut agama yang merasa keberatan). Isu ini dikategorikan sebagai usaha misionaris dakwah keagamaan dan misionaris bangunan-bangunan keagamaan, seperti bangunan rumah ibadah. Isu lain adalah di sekitar pengejawantahan ajaran cinta kasih dalam agama Kristen yang dipandang rawan terhadap penafsiran menjadi ajaran missi agama dalam rangka menarik simpati untuk pindah agama. Prejudice ini muncul selain karena kekurangpahaman terhadap substansi ajaran agama lain, juga karena acuan normatif bersama baik berupa undang-undang maupun aturan-aturan tidak lagi mampu menampung dinamika kehidupan umat beragama.

2. Isu itu belum bergeser dari materi isu yang dianggap klasik dalam arti bahwa hal-hal yang diangkat sebagai isu merupakan sesuatu yang sudah berlangsung lama dalam sejarah hubungan umat beragama di Indonesia. Hanya saja dimensi isu tersebut sekarang menjadi lebih rumit karena sering dikaitkan dengan pihak-pihak atau dimensi di luar hubungan langsung kedua pihak yang saling mencurigai atau sebutlah adanya pihak atau dimensi ketiga yang tidak selalu mudah dapat didentifikasi tetapi sering diduga karena kepentingan politik atau ekonomi.

3. Kerawanan yang terjadi pertama-pertama perlu ditanggapi dari aspek akomodasi normatif berupa pembukaan spektrum yang lebih luas di dalam undang-undang dan aturan-aturan bagi dinamika kehidupan 
beragama yang semakin meningkat. Baik secara teoritis maupun empiris meniscayakan perlunya mengaktifkan kreatifitas para elit agama untuk membangun komunikasi terus menerus baik secara formal maupun nonformal antara mereka. Peran elit dipandang penting, karena selama ini hubungan antar umat beragama di akar rumput tetap berjalan secara harmonis dan alami, sementara pengembangan isu selalu bertumpu pada elit agama. Forum komunikasi umat beragama secara kelembagaan pada tingkat tertentu sudah ada akan tetapi program-program yang dilakukan lebih bersifat formalistik daripada substansial yang menyentuh penyadaran dan pencerahan umat beragama. Kearifan lokal, seperti pangngadakkang atau pangngaderreng di Makassar, yang terkandung dalam tradisi dan adat istiadat diaktifkan kembali sebagai suatu kekuatan perekat antar komponen warga masyarakat yang plural 


\section{DAFTAR PUSTAKA}

Abdullah, M.Amien, Etika dan Dialog Antar Agama, dalam Ulumul Qur'an, Nomor4, VoI.IV.thn 1993.

Abdullah, Taufik, Islam Dan Masyarakat, Pantulan Sejarah Indonesia, Jakarta : LP3ES, 1987.

Ahmad, Abd.Kadir, Potensi Integrasi dan Konflik bagi Kehidupan Beragama, Litbang Agama Makassar, 1986.

Al-Bone, Abd.Aziz (ed.) Profil Kerukunan Hidup Beragama di Indonesia, Balai Penelitian Lektur Keagamaan Ujung Pandang, 1994.

Beoang, K.K. 1997. Michel Foucault; Parrhesia dan Persoalan Mengenai Etika. Penerbit Obor, Jakarta.

Geertz, Clifford, The Interpretation of Culture, New York : Basic Books Inc. Publisher, 1973

Koentjaraningrat, Penelitian Antropologi terhadap Masalah Masyarakat Multietnik dan Kesatuan Nasional, dalam Masyarakat dan Kebudayaan oleh Selo Soemardjan, 1988.

Madjid, Nurcholis, Islam, Doktrin dan Peradaban, Yayasan Wakaf Paramadina, Jakarta, 1992.

Mustoha, H., dkk (penyunting), Bingkai Teologi Kerukunan Hidup Umat Beragama di Indonesia, Litbang Agama, Jakarta 1997.

O'dea, Thomas F, Sosiologi Agama, Rajawali Pres, Jakarta, 1994.

Sairin, Sjafri, Perubahan Sosial Masyarakat Indonesia, Perspektif Antropologi, Pustaka Pelajar, Yogyakarta, 2002.

Wach, Joachim, Sociology of Religion, The University of Chicago Press, Chicago, USA, 1964. 